\title{
Relations among Masculinities: Controversy in Uncle Tom's Cabin
}

\section{Relaciones entre masculinidades: Controversia en La cabaña del tío Tom}

\author{
Luis Fernando Gómez R.*
}

Abstract

The American novel Uncle Tom's Cabin, written by Harriet Beecher-Stowe, has caused historical debate because of its notion of masculinity between white men and African-American slaves in the antebellum period. The description of these two antagonist forces are said to be defined by the author on extreme foundations of sentimentalist and romantic racialism that seem to distort the real objective events related to slavery in America. Beecher-Stowe was condemned by both white and black races because of the denunciation she makes of slavery as a hegemonic male institution. This article examines this polemic in Uncle Tom's cabin, based on the sociologist R.W. Connell's theory of relations among masculinities. From this theory, the article argues that while whites' masculinity is determined by a sense of power based on hegemony, complicity, and subordination, blacks', represented by uncle Tom, is portrayed as adopting weak submission and resigned marginalization. As Uncle Tom's Cabin is the inspiration of a historical reality, this article also studies the novel in relation to factual events in which the ideals of hegemonic masculinity established slavery as a powerful institution in America.

Keywords:

Masculinity, hegemony, complicity, subordination, marginalization, slavery, abolitionists, Christian foundations, Evangelical church.

Resumen

La cabaña del tío Tom, escrita por Beecher-Stowe ha causado debate histórico debido a su noción de masculinidad entre el hombre blanco y el hombre africano durante el período de la esclavitud. Se dice que la autora describe estas dos fuerzas antagónicas con fundamentos extremos de sentimentalismo y romanticismo racial, que parecen distorsionar los hechos reales relacionados con la esclavitud en Estados Unidos. Ambas razas condenaron a la novelista por la denuncia que hace de la esclavitud como una institución hegemónicamente masculina. En este artículo se examina tal polémica en La cabaña del tío Tom, a la luz de la teoría que propone el sociólogo R.W. Connell sobre relaciones entre masculinidades. A partir de ésta, se argumenta el presente artículo que mientras la masculinidad blanca se define por un sentido de poder basado en hegemonía, complicidad y subordinación, la africana, representada por el tío Tom, se caracteriza por adoptar una actitud sumisa, débil y resignada frente a la marginalización. Debido a que La cabaña de tío Tom está inspirada en una realidad histórica, a lo largo del artículo se analiza igualmente la novela en relación con hechos reales, en los cuales los ideales de la masculinidad hegemónica hicieron de la esclavitud una institución poderosa en Estados Unidos.

Palabras claves:

Masculinidad, hegemonía, complicidad, subordinación, marginalización, esclavitud, abolicionistas, fundamentos cristianos, Iglesia evangélica.

Artículo recibido el 20 de marzo de 2007 y aprobado el 30 de abril de 2007

* Profesor del Departamento de Lenguas de la Universidad Pedagógica Nacional. 
We hold these truths to be self-evident, that all men are created free and equal; that they are endowed by their Creator with certain inalienable rights; among these are life, liberty, and the pursuit of happiness.

Declaration of American Independence

The antebellum period in the USA was a time of dramatic socio-political concerns in which many ideological modes emerged around the slavery conflict. The abolitionists' ideals of setting blacks free were mostly unaccepted by average white men whose economic interests depended on the submission of slaves. The romantic racialism, which proclaimed kindness for the humane treatment of slaves and sympathy to the antislavery argument -as for it "slavery constituted the oppression of 'one of the best races of the human family"' (Fredrickson, 437)- strongly opposed the notions of the superiority of the white man who degraded African-American race. There was also a contradicting conception of America as a democratic nation since the ideals of human equality and freedom were being censored by the practice of slavery. In addition to that, the public's acceptance of violence, abuse, and intimidation as efficient methods to exercise on slaves became a social construct in the south, and religious communities such as the Evangelical church and the Methodist Episcopal Church raised concerns about the moral degradation that the white man was going through. Even more, there were strong overtones of a civil war likely to happen since the United State Congress had also passed the second Fugitive Slave Act in 1850, which punished those who helped runaway slaves to go to freed states. This law brought disappointment among anti-slavery citizens in the North because it made them responsible for supporting slavery. Within this social turmoil, Uncle Tom's cabin was published in 1852, mainly as a reaction to the Fugitive Slave Act, and it brought even more controversy to the slavery issues.

Uncle Tom's cabin is a novel that causes debate. One of its most controversial topics is its notion of masculinity, in which whites' manliness is portrayed by a sense of power based on hegemony and complicity, while blacks' masculinity, represented by Uncle Tom, is conceived on submission and pure moral foundations. Beecher-Stowe demonstrates in the novel that one of these masculinities is stronger than the other. Since masculinity is a social construction and involves cultural ideology, she develops the building of both black and white masculinities in the novel in very different ways. In order to understand the notion of masculinity in Uncle Tom's Cabin, a comparative approach between white and black males, as depicted by BeecherStowe, will be established based on the theoretical model named Types of masculinity proposed by the sociologist R.W. Connell. This model conceives that the relationships among male individuals consist of four categories of masculinity: hegemony, subordination, complicity and marginalization. Connell affirms, "We must recognize the relations between the different kinds of masculinity: relations of alliance, dominance, and subordination. These relations are constructed through relations that exclude and include, that intimidate, exploit, and so on. There is a gender politics within masculinity" $(2005,37)$. This idea relates to the exercise of power among male figures in Beecher-Stowe's Uncle Tom's Cabin. Her novel clearly shows opposite relations of dominance, subordination, exploitation, and exclusion between black and white males. Therefore, Connell's model of types of masculinity elucidates not only how these relationships functioned in the antebellum society, but how Beecher-Stowe pictures them to demonstrate that slavery was a wrong institution.

Hegemony, the first category of Connell's theory, refers to a cultural dynamic through which a male group sustains a leading position in social life. This group is generally exalted $(2005,77)$ and is established by cultural ideals and institutional power. In this sense, being the American society mainly a patriarchal society in the time of slavery, many white men popularized their supremacy by defining themselves a superior race. In fact, Thomas Jefferson in his Notes of the State of Virginia had noted in 1785 that he not only believed in black inferiority, but was convinced that blacks could never become citizens 
of the United States, being this a clear expression of masculine hegemony:

I advance it, therefore, as a suspicious only, that the blacks, whether originally a distinct race, or made distinct by time and circumstances, are inferior to the whites in the endowments both of body and mind ... This unfortunate difference of color, and perhaps of faculty, is a powerful obstacle to the emancipation of these people... The slave... when freed, he is to be removed beyond the reach of mixture (compiled by Levine, 2000, 341).

Since hegemony is a product resulting from cultural ideals, Caucasian men considered that, as being white, they had the power to exploit black males because they were, in words of Jefferson, "in reason much inferior" (compiled by Levine, 2000, 338) and, therefore, could be used as essential means to achieve whites' economic goals. Thus, reducing Africans to slaves became socially and culturally a normal practice based on the conception of superiority and inferiority. In this sense, masculine hegemony became a destructive social force. According to Robert Moller, citing Mike Donaldson, hegemonic masculinity is "exclusive, anxiety-provoking, internally and hierarchically differentiated, brutal and violent. Among its defining features are misogyny, homophobia, racism and compulsory heterosexuality" $(1998,608)$. Beecher-Stowe depicts this idea in the novel in many instances, one of which that is worth citing in the very first chapter, when Mr. Shelby is trading the sale of some of his slaves with Haley, a slave trader. This scene basically shows not only how white men have the power to decide on the lives of black people as they buy and sell them, but their incredulity, especially Haley, that black men are able to be good Christians, "Some folks don't believe there is pious niggers," (2) implying that slaves were inferior to really have a Christian mode of life as white men did. In the same way, Mr. Shelby decides to sell Eliza's little black boy without any concern about separating him from his mother and breaking one of the most sacred institutions of society, the family. This action clearly demonstrates, as Moller points out, the brutality of white masculine hegemony since we can observe that the boy represents the future masculinity of the black race, but before he becomes a man, his masculinity is already being subordinated.

These initial events cited from the novel are just a minimum part of the controversy that Uncle Tom's Cabin caused. Slaveholders reacted against BeecherStowe's novel, arguing that it was a vulgar distortion of slavery. However, historical references show that white masculinity was culturally characterized by a strong notion of superiority and, in the words of Moller, by a sense of "compulsory heterosexuality." Griffin Wolff states that whites believed that African Americans were by "nature" emotionally, intellectually, and morally inferior. They were seen more like animals than people $(1995,597)$. Equally, George Fredrickson explains that the superiority of white men was a common idea among critics of the slave system. He refers to Theodore Parker, liberal Unitarian minister, who declared, "I look at great pride on this Anglo-Saxon people. It has many faults, but I think it is the best specimen of mankind which has ever attained great power in the world" $(1987,432)$. Undoubtedly, white men created a high sense of superiority of their own image by means of looking down other races and popularizing it as an acceptable cultural construct to justify slavery.

Even more, whites' heterosexuality was conceived to the extreme. Masculinity meant to be physically violent, rude, and uncompassionate because these exaggerated behaviors principally guaranteed hegemonic control on male slaves, who after all were men and had the same masculine conditions than whites did and, therefore, could engage into rebellion. Clear testimony of this violent heterosexuality is presented in the reactions that many antislavery leaders accounted for the horrors of their masculine power, "the whites have always been an unjust, jealous unmerciful, avaricious and blood thirsty set of beings, always seeking after power and authority ... we see them cutting each other's throats -trying to subject each other to wretchedness and misery" (Walker, compiled by Levine, 2000, 355). This testimony, addressed by David Walker, son of a slave father and an influential abolitionist, is not only impregnated by 
indignation and anger, but reveals whites' excessive masculine brutality up to the point that they kill each other in order to keep power. Being endowed with this violent behavior and craving for power, white men believed they were right to trade with slaves and treat them as they wanted. The moral, educational, and cultural conceptions of what being a man really meant acquired belligerent meanings and distorted the principles of the Declaration of Independence which advocated the equal rights for all human beings. Griffin Wolff explains that, "men were using manliness with new meanings; they were also creating a society based on the free expression of the traditional manly passion: assertiveness, ambition, avarice, lust, power" $(1995,599)$. Because of this kind of dominant masculinity, the moral code and the democratic ideals of white men were breaking apart. Beecher- Stowe could not have been unaware of this reality. In one of the letters she wrote to her editor about the writing progress of her novel, Uncle Tom's Cabin, she explains:

I am at present occupied upon a story which will be much longer than any I have ever written, embracing a series of sketches which give the light and shadows of the 'patriarchal institution,' written either from observation, incidents that have occurred in the sphere of my personal knowledge, or in the knowledge of my friends. I shall show the best side of the things and something faintly approaching the worst" (compiled by Reynolds, 1985, 8).

These words show her opinion on the masculine power of her time. She intentionally quoted the words "patriarchal institution" to emphasize how American society was infested by the predominant power of male members. We also deduce from her words that she refers to patriarchy as an "institution" to ironically remark that it was built on men's evil behavioral patterns in order to keep hegemony. In addition, she states that she will show something "faintly approaching the worst," to suggest that she would not be able to show in her novel all the cruel reality as it actually happened because whites' evil powers to inflict on slaves went beyond description. This leads us to observe that if Uncle Tom's cabin would not have been written with the gentle sentimentalism and Christian symbolism that characterized Beecher-Stowe's narrative style, the truths she revealed in the novel had been devastating. Thus, Uncle's Tom Cabin is just a subtle recreation of patriarchal hegemony compared to what the history of the US really has to say. Equally, BeecherStowe's attitude in the previous fragment stand for one of the abolitionist ideals which claimed that slavery was an expression of oppressive, hierarchical patriarchy (Griffin, 1995, 601). She intended to remodel, according to critic Askeland, traces of slave history to create narratives that will also remodel the ideologies that dominated patriarchal structures $(1992,877)$.

Complicity is the second category that, according to Connell, determines relations among masculinities. This category refers to the extension and institutionalization of a male power group under mutual agreements. Thus, a group agrees on the procedures through which subordination is going to be carried out. Hegemony is not actually effective if a careful and strategic plan is not well designed to guarantee power control. That is why complicity is a cautious conspiracy and one of the main important factors in the power of masculinity because it refers to the intellectual planning to dominate other groups. The document American Slavery as It Is, written in 1839 by Theodore Dwight Weld, antislavery leader, denounces that "... the slaves in the United States are treated with barbarous inhumanity ... by magistrates, by legislators, by professors of religion, by preachers of the gospel, by governors of state, by 'gentlemen of property and standing,' and by delicate females moving in the highest circles of society" (compiled by Levine, 2000, 267). This historical document divulges how masculine complicity was socially and politically well-organized. All of the influential and intellectual men in the political, educational and religious sectors of society established a conspiring plot to show slavery as a legalized institution. Even "delicate women" were part of that hegemonic complot, which suggests that females agreed with the horrors of the antebellum patriarchal institution. 
A clear case of complicity in Uncle Tom's Cabin is obviously the slavery system, which was based on intimidation. Whites knew that a wise strategy to keep blacks' obedience was to whip them so that this punishment was an example to those who intended to revolt against the system. Legree's inhuman violence to tame uncle Tom is a vivid instance of that repressed system as he gets Tom whipped to death from this punishment. Also, as seen in chapter seven, Hanley and his men run after Eliza and her boy to capture her before she passes the line of Kentucky to a free state. In a very dramatic moment in which Eliza is about to be caught by her pursuers, she manages to cross the icy and turbid current of the Ohio River in order to escape. As she sees a known man on the other shore, she requests him to help her pass the Ohio side, "Oh, Mr. Symmens! -save me, do save me, do hide me! ... My child! This boy! he'd sold him! There is his Mas'r, said she, pointing to the Kentucky shore" (52). Luckily, Eliza and her boy succeeded in going to a free state, but many were caught before going too far. As can be seen, this passage is inspired on another lawful practice that whites had established to have slaves persecuted in their intent to escape. These methods of repression established by mutual complicity are a social creation to sustain whites' hegemonic masculinity. That is why male complicity aims at silencing and subordinating others as the hegemonic group imposes a set of rules granted with political legitimacy that are expected to be obeyed.

The previous examples mentioned from the novel parallel the historical reality of Beecher-Stowe's time. A federal act in 1793, named the Fugitive Slave Law, and the Second Fugitive Slave Law, later legalized in 1850, were created to force runaway slaves return to their owners so that blacks had less possibilities to try to escape to the free north states. This new complicity among those who favored slavery was precisely adopted when anti-slavery reactions started openly to increase. The hegemonic masculine society thought that a good strategy to control the black race was to create new repressed methods. In this way, they maintained their regime in complicity and cooperation with other slave states to help whites get their runaway slaves returned to their slaveholders. A segment of the Fugitive Slave Law, 1793, states that,

it is further agreed ... that neither shall entertain, or give countenance to, the enemies of the others, or protect, in their respective states, criminal fugitives, servants, or slaves, but the same to apprehend and secure, and deliver to the state and states, to which such enemies, criminals, servants, or slaves, respectively belong (art. 4).

This is a vivid example of hegemonic complicity which tactically describes runaway blacks not only as servants and slaves, but as "enemies" and "criminals" in order to enhance blacks' level of inferiority even worse than the regular position they had as slaves living with their slaveholders. The craving for freedom of black men from whites' was seen as a criminal action. However, being unsatisfied with this first law, white hegemonic complicity engaged in a shameless second attempt to maintain slavery with a new legal institution in 1850 . The Second Fugitive Slave Law stated that:

And be it further enacted, that it shall be the duty of all marshals and deputy marshals to obey and execute all warrants and precepts issued under the provisions of this act, when to them directed; and should any marshal or deputy marshal refuse to receive such warrant, or other process, when tendered, or to use all proper means diligently to execute the same, he shall, on conviction thereof, be fined in the sum of one thousand dollars, to the use of such claimant, on the motion of such claimant, by the Circuit or District Court for the district of such marshal; and after arrest of such fugitive, by such marshal or his deputy, or whilst at any time in his custody under the provisions of this act, should such fugitive escape, whether with or without the assent of such marshal or his deputy, such marshal shall be liable, on his official bond, to be prosecuted for the benefit of such claimant, for the full value of the service or labor of said fugitive in the State, Territory, or District whence he escaped (sec. 5).

The extremist determinations of complicity took Southern white men to threaten Northern white 
officials and jurors if they did not obey the law and did not arrest runaway slaves. Measures such as federal marshals, a fine of $\$ 1,000$, and six months imprisonment exemplify the radically strategic methods and procedures that masculine hegemony was determined to reach, even by getting other white men involved in the conflict and punishing them if necessary. Hegemony and complicity have no limits to maintain power. Undoubtedly, the creation of these laws clearly corroborates the words stated by Walker previously cited that whites are "beings, always seeking after power and authority ... we see them cutting each other's throats -trying to subject each other to wretchedness and misery" (compiled by Levine, 2000, 355).

There is no more terrifying evidences of hegemonic complicity as Mora Reynolds reports on her book Uncle Tom's Cabin and Mid-Nineteenth Century in United States about how African people were brought to America:

Ships crews were in constant dread of being overpowered by their captives and took precautions to prevent this. Persons known to speak the same language were separated from each other, and periods of exercise on the deck were kept to the minimum. This meant that for most of the time the natives were in the airless, cramped hold that reeked. The Negroes were put in irons, two and two together, according to Newton, "the right hand and foot of one to the left of the other, but across -so that they cannot move either hand or foot, but with great caution and perfect consent." Shackled thus, the blacks were forced to lie in their own urine and faces during the middles passage; the average duration was 60 days. The mortality (including suicides) for Africans on the middle passage averaged about 13 percent. Smallpox and dysentery were very common, and of course the frightful conditions below deck contributed to the spread of infectious diseases. Also, with limited rations, malnutrition was widespread. When the captives were allowed on deck, they exercised to a whip $(1985,47)$.

This fragment reveals the merciless and degenerate "legal" procedures that hegemonic masculine individuals implemented to maintain their dominance safe. Interestingly, Mora Reynolds avoids saying directly who provided those atrocious conditions. In her report, she uses passive voice, "Negroes were put," "were separated," and "were forced," stressing the level of complicity and conspiracy of whites' mutual sinister plans. All their names were protected and unsaid by means of imposing a collective agreement on how to treat slaves. This evades the direct responsibility of the leaders of hegemonic social power who cannot be accused individually. The responsibility is communal as they manage the way to protect their names. Thus, strategically, it is the system and the laws to be blamed, not the leaders or the men who invented them.

Complicity also reaffirms hegemonic masculinity "on how men should behave and how putative 'real men' do behave, as the cultural ideal" (Morrel, 1998, 608). As mentioned before, white men created a code based on aggressiveness, ambition, racism and a compulsory heterosexuality in order to determine a particular model of masculinity through which they could hold power. Thus, whites' male hegemonic behavior is the product of complicity. This idea is presented in the novel Uncle Tom's Cabin in the long discussion on slavery that Ophelia has with Saint Clare in chapter XIX. Saint Clare suggests that he has slaves because he inherited that tradition from his family, and because he cannot do anything to go against the system. He recognizes that slavery is evil and whites are hypocritical as he says, "Besides, that ours is the more bold and palpable infringement of human right; actually buying a man up, like a horse, appropriating human beings to the use and improvement of another, without any regard to their own" (200). Later he says, "some how or other, instead of being actor or generator of society, I became a piece of drift-wood, and have been floating and eddying about, ever since" (201), implying that he will do nothing to change the system, even though he knows it is wrong. Evidently, this is an indication of cynical masculine complicity. He is accepting the rules imposed by his race and, in depth, he is careless about the "infringement of human right" he makes because, after all, he is taking advantage 
of the situation in order to please his own materialistic benefit.

The third level of masculinity, according to Connell, is subordination, which deals with any political and cultural exclusion, including legal violence to dominate another masculine group $(2005,78)$. It directly has to do with the actual performance of authoritarian power based on the methods of control that have been established. Thus, subordination involves the practice of physical and psychological abuse, punishments, economic, social, and cultural discrimination, verbal insult, humiliation of any kind, personal boycotts, and even condemnation to death, if necessary. Subordination, then, becomes corrupt and immoral.

To this respect, Beecher-Stowe wrote Uncle Tom's Cabin to show the horrors and abuse of slavery, which were inflicted by the whites' masculine ideology. Davison Reynolds states that "Uncle Tom's Cabin deals with chattel slavery as it existed in the Unites States" (1985: 23), that is to say, BeecherStowe's novel is real-life based material which denounces the hegemonic code of racist and cruel slaveholders' actions against black race. This novel obviously caused controversy among whites who believed that slavery was a noble action. Whites were convinced that they were benevolent because slavery was divine providence and God had predisposed Africans' fate to be submitted since they were thought to be animal like and inferior, and because, in a deeper sense, slaves' labor was a profitable business tactic that provided whites the means to increase their fortunes.

In chapter three of Uncle Tom's Cabin, George complains about his desperate condition for being a victim of subordination. He claims, "I wish I'd never been born myself ... What's the use of living? I wish I was dead," (13) because he realizes he has been used and abused. George has been a hard-working person in his master's factory; he has become an excellent manager and has invented a new machine to save time and work. But in spite of his efficient labor, his master, afraid of George having greater intelligence than him, punishes him in return. George is not allowed to see his wife and his son anymore who happen to belong to another master, and he is told to find another black woman to live with in the factory. George's situation exemplifies how blacks' masculinity was disregarded at all levels. George's working abilities are ignored, he is separated from his family and, even worse, his marriage is not recognized by any official law. Stone describes how George's master imposes his hegemony when she narrates, "The tyrant . . . inwardly strengthened himself in his determination to keep the power he possessed over his victim" (11). Under these circumstances, George is unhappy of his life and, as he sees his little boy, and thinks of the miserable life that his child is expected to live, he wishes his own son had never been born because there is no future for blacks to be free. Thus, blacks were victims of total despair and frustration, being these effects caused by masculine subordination.

Another example of masculine subordination that Beecher-Stowe portrays in the novel is Legree's attempt to dominate Tom in body and soul. The confrontation between these antagonist masculinities is clearly based on hegemonic power in which Legree submits Tom by using a method of verbal abuse and physical cruelty until Tom is humiliated to the lowest level of marginalization. She pictures Legree's dominant masculinity as full of "anger," having "fiercely" eyes and "passion," and "like some ferocious beast that plays with its victim before it devours it" (309). He represents the compulsively racist characteristics of manhood that turn out to be animalized, since he acts like he has an irrational impulse of rage. Legree subordinates and humiliates Tom's masculinity when he says, "Well, here is a pious dog, at last, ... didn't you never hear, out of your Bible, 'Servants, obey yer master'? An't I yer master? Didn't I pay down twelve hundred dollars, cash, for all there is inside yer old cussed black shell? Ain't yet mine, now, body and soul?" and then proceeds to give Tom "a violent kick with his heavy boot" (309). As Legree emphasizes that Tom is completely his property because Legree paid much money for him and that Tom's body and soul is Legree's now, it is implied that Tom's personal identity and masculinity is totally annulled by his hegemonic oppressor. 
Tom is not even a male for Legree, but just a simple "dog" and a miserable "black shell."

The last category in Connell's theory about relations among masculinities is marginalization. It involves the relationship between masculinities in dominant and subordinated classes or ethnic groups. Marginalized masculinity in Uncle Tom's Cabin is, in this sense, mainly focused on the black males' role. As can be seen throughout the novel, blacks are pushed to the most hideous indignant level of existence. In the particular case of black males, their masculinity was completely opposite to whites'. While whites gave orders and decided on their lives, black males obeyed and were not even able to make important decisions about their own families because their wives and children were whites' private property. They could not even make decisions about themselves. As being a submissive group, whites labeled blacks as docile and passive males. In 1836, Charles Stuart, a British abolitionist wrote an article for a popular magazine of the time in which he refers to blacks as being "eminently gentle, submissive, affectionate and graceful" (Fredrikson, 1987, 434). Equally, they were stigmatized as"willing to serve, the most beautiful trait of humanity, which we (whites), from our own innate love of domination, and defiance of the Christian religion, brand with the name of servility, and abuse not less to our own dishonor than to their injury" (ibid).

Since black men constituted a subservient kind incapable to freely express their masculinity on normal basis and in correspondence to their African cultural ideals, Beecher-Stowe portrays black males, in spite of their circumstances, developing another type of masculinity. Such, was based on a strong Christian faith resembling the masculinity of Jesus Christ. Uncle Tom emerges as a strong and enduring man who is able to undergo suffering and humiliation and who is adhered to a fixed Christian moral. All his actions and thoughts reflect a fortified connection with God's designs. In one of the moments of confrontation between Legree's and Tom's masculinities, Legree asserts, "I'll conquer ye, or kill ye, one or t'other. I'll count every drop of blood there is in you, and take 'em, one by one, till ye give up!" (359).
Through these words, Legree means that either way, conquering or killing, he will be the winner and Tom the loser. However, Tom's Christian power emerges. At the agonizing moment of his death, Tom forgives his tyrant master and dies in the name of love for others and in the name of God, his real master. Indeed, in one of the prior scenes when Legree affirms that Tom will be his in body and soul, Tom exclaims, "No! no! no! my soul ain’t yours, Mas'r. You haven’t bought it, ye can't buy it! It's been bought and paid for, by one that is able to keep it" (309), we deduce that the one who already possesses his soul is God. Through Tom's characterization, then, Stowe, who opposed slavery, wanted to show blacks as being strong and masculine in spirit and faith, suggesting that Tom's masculinity parallels that of Jesus Christ's, who endured humiliations and became a hero by leading a conduct of obedience and self-sacrifice. As Tompkins argues, this novel rewrites the Bible as the story of a Negro slave $(1985,512)$. So, BeecherStowe's main intention, as being an active member of the Christian Evangelical church, was to show the American society that the imposition of hegemony and subordination of human beings was an evil practice and that, therefore, whites' complex of superiority had gone too far. As Gail K. Smith notes, "drawing together her abolitionist sympathies and her interests in language, biblical interpretation, and preaching ... Beecher-Stowe also seeks to educate her reader through her novel's juxtaposition of biblical arguments on slavery" $(2001,226)$. BeecherStowe believed that ruthless masculinities based on despotic power and compulsive expression of brutal manly behaviors had taken men away from moral decency. Her lesson is that in which self-sacrifice and spiritual fortress, those that sympathize with the male conduct of Christ, are the ones to be adopted by American males and slaveholders because, it is deduced, that it is the most powerful and authentic expression of masculinity. Once men love others and see them at the same level, human submission no longer exists.

However, as mentioned before, Beecher-Stowe's intention caused collective debate. White men referred derogatorily to the novel as a sentimental 
and a ridiculous story which had distorted reality. One of the most famous critics against Uncle Tom's Cabin, James Baldwin, argued that "it is a very bad novel, having, in itself-righteous, virtuous sentimentality much in common with Little Women. Sentimentality, the ostentatious parading of excessive and spurious emotion ... Her book was not intended to do nothing more than prove that slavery was wrong; was, in fact, perfectly horrible" $(1949,496)$. On the other hand, black men also reacted negatively to the novel. They argued that Beecher-Stowe's description of Tom as a weak and submissive creature willing to accept passively any kind of maltreatment intensified even more the subordination of slaves and promoted the abuse of their race. It was also conceived that blacks' masculinity had been feminized and therefore, Uncle Tom's Cabin had offended their masculine pride. Griffin Wolff affirms that by the time the novel became a success, Tom's manliness had been compromised since his aggressive masculinity relinquished for the most feminine values of sentiment $(1995,598)$. As Beecher-Stowe defines her characters with romantic racialism and sentimentalism, that is to say, she often idealizes slaves having good-hearted nature and pious resignation, Tom was misunderstood by having feminine characteristics, which contrasted all the crude masculine code of the antebellum period.

To a certain extent, Tom's masculine passivity is not easy to be accepted by many readers keeping in mind that Legree is pictured having an abominable masculine behavior as he feels pleasure gradually killing uncle Tom to demonstrate his hegemony. But Beecher-Stowe's Evangelical notion of masculinity functions in a deeper and more sublime way for readers who prioritize a particular spiritual interpretation above the issues already discussed. It is not only the fight between two males, but it is also the representation of the eternal fight between good and evil. These two forces are wisely represented by the compulsive masculinization of a corrupt hegemonic tyrant and a defenselessly benevolent victim. Beecher-Stowe's idea is that masculinity can be good, not evil, and that is why Tom has to die. If we consider for a moment that Tom had reacted with rage and vengeance in order to defend his life and had killed Legree, he would have become contaminated by the whites' hegemonic brutal code. Consequently, he would have become as ruined as his antagonist. Beecher-Stowe's point is that masculinity is to be away from the ideas of power, rudeness, and violence because it is a false social and cultural construction. In other words, due to her religious influence, she believed, paraphrasing in modern terms, that if there should be a cultural construct of masculinity, it should be constructed on ethical and moral Christian foundations.

Relating this idea to Connell's model of relation among masculinities (hegemony, complicity, subordination and marginalization), it may be difficult to accomplish Beecher-Stowe's notion of Christian masculinity, since, according to Connell and Morell, relations among masculinities generally function and have functioned on power, aggression, and competitiveness. However, Beecher- Stowe's proposal of masculinity was not an impossible task. It did not mean to suffer and sacrifice in the literal sense as many may have understood. She wanted to show that one of the ways to abolish slavery was to change men's hearts. After all, her proposal was defined on normal ethical and moral principles that should be part in the social practice of normal masculinity. However, the controversy on Uncle Tom's Cabin still continues as hegemonic masculinity continues. She made a reasonable point, but the controversy relies in the fact that the radical ideas of hegemony, complicity, and subordination of our patriarchal society were precisely the ones that marginalized her work. \} 


\section{References}

Askeland, Lori (1992). Remodeling the Model Home in Uncle Tom's Cabin and Beloved. American Literature. 64, 4, 785-805.

Baldwin, James (1949). Everybody's Protest Novel. Notes of a Native Son. New

York: Dial Press. (This review is also included in the Norton Critical Edition of Uncle Tom's Cabin).

Banks, Marva (1993). Uncle Tom's Cabin and the Antebellum Black Response.

Readers of History: Nineteenth Century American Literature and The Contexts of Response, James L. Machor. Baltimore, Md.: Johns Hopkins UP.

Connell, R. W. (2005). The Social Organization of Masculinity," in Masculinities. Cambridge: Polity P.

Dwight, Theodore (2000). American Slavery As It Is. Sources and revisions in Clotel or The President's Daughter. Boston: University of Maryland.

Griffin Wolff, Cynthia (1995). Masculinity in Uncle Tom's Cabin, American Quarterly 47, 595-618.

Fredrickson, George M. (1987). Uncle Tom and the Anglo-Saxons: Romantic Racialism in the North. Uncle Tom's Cabin, A Norton Critical Edition, 429-38.
Jefferson, Thomas (1904). The Works of Thomas Jefferson. New York: G.P. Putnam's Sons.

Morrel, Robert (1998). Of Boys and Men: Masculinity and Gender in Southern

African Studies. Journal of Southern African Studies, vol. $24, \mathrm{~N}^{\circ} 4$, Special Issues on Masculinities in South Africa, 605-630.

Reynolds, Mora Davison. (1985). Uncle Tom's Cabin and Mid-Nineteenth Century in United States Jefferson: Jefferson: McFarland \& Company, Inc, Publishers.

Smith, Gail K (2001). The Sentimental Novel: The Example of Harriet Beecher Stowe. Nineteenth Century American Women's Writing. NY: Cambridge UP, 221-243.

Tompkins, Jane (1985). Sentimental Power: Uncle Tom's Cabin Power and the Politics of Literary History. Sensational Designs: The Cultural Works of American Fiction, 1790-1860. Oxford: Oxford UP.

Walker, David (1995). Appeal in Four Articles, 1830. New York: Hill. Federal Act of 1793 and 1850, the Fugitive Slave Law. 